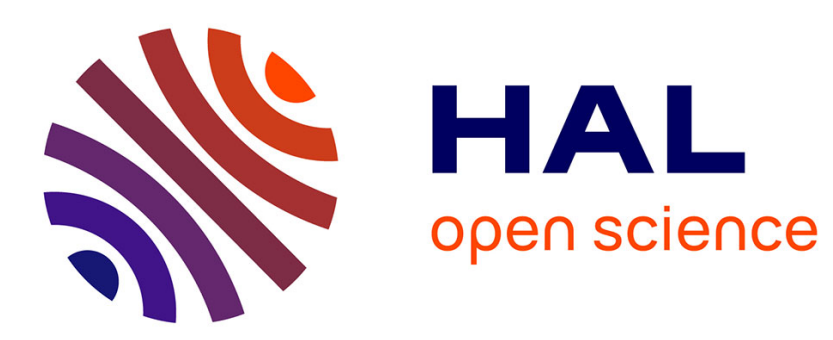

\title{
Paleogene building of the Bolivian Orocline: Tectonic restoration of the central Andes in 2-D map view
}

César Arriagada, Pierrick Roperch, Constantino Mpodozis, Peter R. Cobbold

\section{To cite this version:}

César Arriagada, Pierrick Roperch, Constantino Mpodozis, Peter R. Cobbold. Paleogene building of the Bolivian Orocline: Tectonic restoration of the central Andes in 2-D map view. Tectonics, 2008, 27 (6), pp.TC6014. 10.1029/2008TC002269 . insu-00356242

\section{HAL Id: insu-00356242 \\ https://hal-insu.archives-ouvertes.fr/insu-00356242}

Submitted on 30 Jun 2016

HAL is a multi-disciplinary open access archive for the deposit and dissemination of scientific research documents, whether they are published or not. The documents may come from teaching and research institutions in France or abroad, or from public or private research centers.
L'archive ouverte pluridisciplinaire HAL, est destinée au dépôt et à la diffusion de documents scientifiques de niveau recherche, publiés ou non, émanant des établissements d'enseignement et de recherche français ou étrangers, des laboratoires publics ou privés. 


\title{
Paleogene building of the Bolivian Orocline: Tectonic restoration of the central Andes in 2-D map view
}

\author{
C. Arriagada, ${ }^{1}$ P. Roperch, ${ }^{2,3}$ C. Mpodozis, ${ }^{4}$ and P. R. Cobbold ${ }^{2}$ \\ Received 26 January 2008; revised 18 September 2008; accepted 9 October 2008; published 24 December 2008.
}

[1] Using available information on the magnitude and age of tectonic shortening, as well as paleomagnetically determined tectonic rotations, we have run a series of 2-D map view restorations of the central Andes. Neogene shortening in the foreland belt induced only slight orogenic curvature of the central Andes. The constraints on the ages of the large observed fore-arc rotations (average of $37^{\circ}$ counterclockwise in southern Peru and $29^{\circ}$ clockwise in northern Chile) indicate that the Bolivian Orocline formed during the EoceneOligocene as a consequence of differential shortening focused in the Eastern Cordillera. To minimize local block rotations along the fore arc, the restoration that best fits the central Andean rotation pattern requires about $400 \mathrm{~km}$ of total (Paleogene plus Neogene) shortening near the Arica bend. This value corresponds to the upper bound of estimates of maximum horizontal shortening for the central Andes. Along-strike variations in horizontal shortening in the back arc induced bending of the continental margin, block rotations with fore-arc along-strike extension, and/or orogen-parallel transport of upper crustal material toward the symmetry axis of the orocline. Citation: Arriagada, C., P. Roperch, C. Mpodozis, and P. R. Cobbold (2008), Paleogene building of the Bolivian Orocline: Tectonic restoration of the central Andes in 2-D map view, Tectonics, 27, TC6014, doi:10.1029/2008TC002269.

\section{Introduction}

[2] Two of the most remarkable tectonic features of the western South American continental margin are the curvature of the orogenic system in the central Andes at $20^{\circ} \mathrm{S}$ (Arica bend or Bolivian Orocline) and the pattern of block rotations, clockwise in northern Chile and counterclockwise in southern Peru (central Andean rotation pattern (CARP) [Beck, 2004; Taylor et al., 2005]) (Figure 1). Several authors have tried to relate the origin of the CARP to the processes that shaped the Bolivian Orocline. Isacks [1988] hypothesized that the Bolivian Orocline formed as a consequence of

\footnotetext{
${ }^{1}$ Departamento de Geología, Universidad de Chile, Santiago, Chile.

${ }^{2}$ Géosciences Rennes, UMR6118, Université de Rennes, CNRS, Rennes, France.

${ }^{3}$ LMTG, Université de Toulouse, IRD, Toulouse, France.

${ }^{4}$ Antofagasta Minerals, Santiago, Chile.
}

Copyright 2008 by the American Geophysical Union. 0278-7407/08/2008TC002269 the geometrical restrictions imposed by along-strike changes in the magnitude of Neogene horizontal shortening along the sub-Andean zone, changes which need to be accompanied by tectonic rotations in the fore arc.

[3] Allmendinger et al. [2005] used geodetic data to argue for ongoing bending of the Bolivian Orocline. Present-day along-strike changes in the magnitude of shortening which may eventually lead to the formation of the Orocline, if extended back in time, have been additionally illustrated by Khazaradze and Klotz [2003] and Kendrick et al. [2006]. After removing the elastic GPS signal associated with interseismic locking along the plate boundary, they showed that permanent deformation rates in the southern central Andes decrease from $\sim 6-9 \mathrm{~mm} / \mathrm{a}$ in the Bolivian Andes to less than $3 \mathrm{~mm} / \mathrm{a}$ in the Argentine Precordillera.

[4] Most authors agree that mid-Neogene to present deformation is mainly localized in the sub-Andean zone, for which the estimates of shortening based on seismic data are relatively well constrained (see Oncken et al. [2006] for a recent review). However, although there is a consensus that the deformation began in the early Tertiary, the total amount of shortening is debated. Many estimates of shortening are not large enough to account for the present-day topography and crustal thickness [Beck et al., 1996; Kley and Monaldi, 1998].

[5] By progressively removing the accumulated horizontal shortening, several authors have tried to reconstruct the development of the Bolivian Orocline and to restore the original shape of the Andean margin [e.g., Baby et al., 1993; Kley, 1999; McQuarrie, 2002a]. However, because the tectonic architecture of the central Andean region results from an intricate combination of thrusting, wrenching, and block rotations, a realistic 2-D map view restoration of the central Andes should be constructed from balanced cross sections and tectonic rotations constrained by paleomagnetic data.

[6] Lamb [2000] attempted to reconstruct the horizontal velocity field in the Bolivian Andes by combining geodetic and paleomagnetic data, but he took into account only the shortening in the sub-Andean belt. Riller and Oncken [2003] provided a simple shear plan view model that predicts the Neogene kinematics of first-order fault zones and paleomagnetic rotations of the back-arc region in the southern central Andes. Barke et al. [2007] provided a detailed model of the recent evolution of the southern Eastern Cordillera of Bolivia but restricted the analysis to the last $10-15 \mathrm{Ma}$. Using a map view kinematic model of the Bolivian Orocline, Kley [1999] suggested that the largescale rotations of the limbs of the orocline are markedly smaller than those derived from paleomagnetic data and 

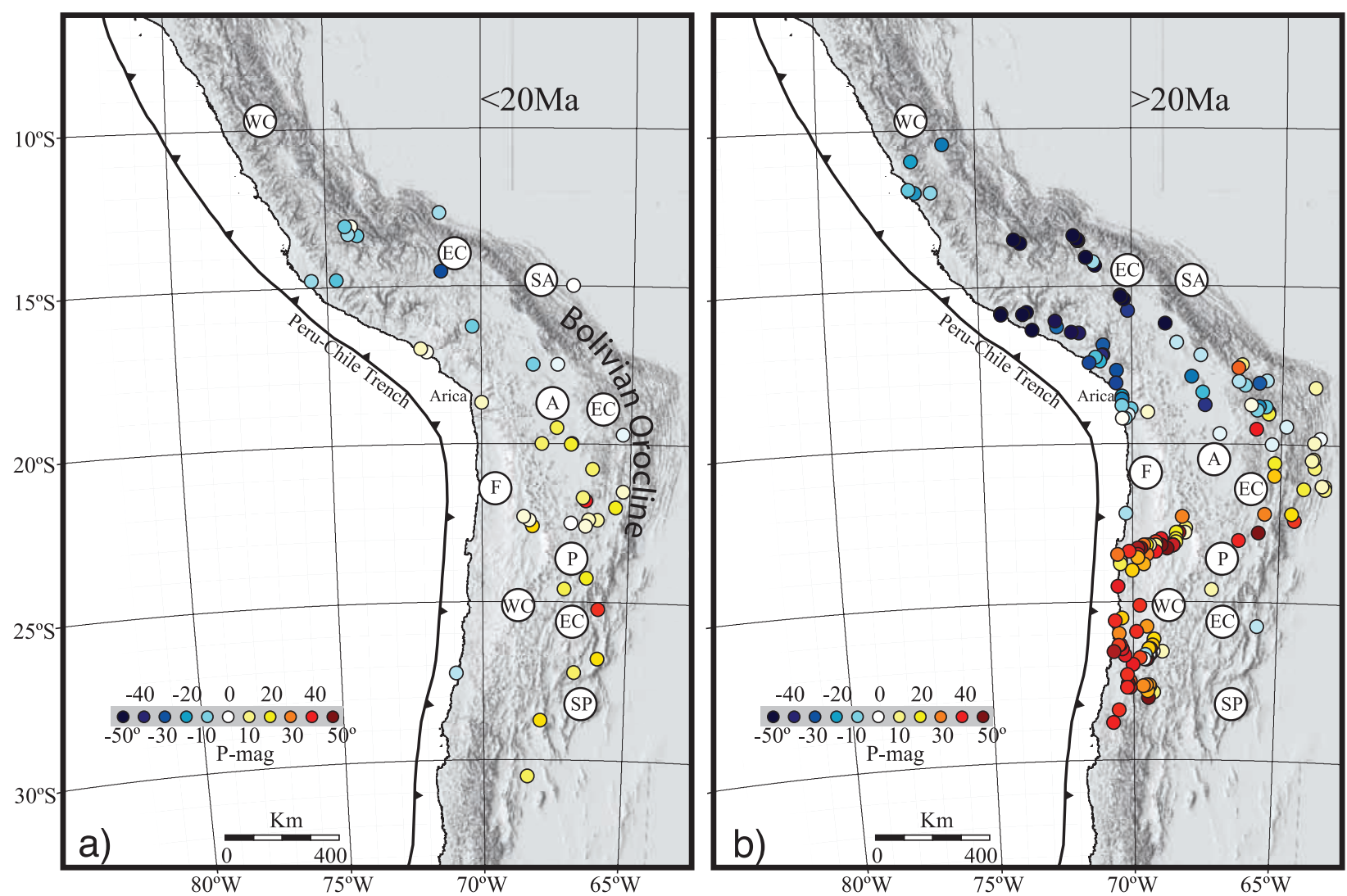

Figure 1. Paleomagnetic database along the central Andes. Paleomagnetically determined block rotations about vertical axes are shown as circles (a) for rocks younger than $20 \mathrm{Ma}$ and (b) for rocks older than $20 \mathrm{Ma}$. Clockwise (counterclockwise) rotations are shown in red (blue). F, modern fore-arc region; WC, Western Cordillera; A, Altiplano; P, Puna; EC, Eastern Cordillera; SA, sub-Andean zone; SP, Sierras Pampeanas. An up to date paleomagnetic database for the northern central Andes is given by Roperch et al. [2006] (see auxiliary material, available at ftp://ftp.agu.org/apend/tc/2005tc001882) and for the southern central Andes by Arriagada et al. [2006] (see auxiliary material, available at ftp://ftp.agu.org/ apend/tc/2005tc001923).

probably are of the order of $5^{\circ}-10^{\circ}$. The magnitudes of the measured rotations, on average $37^{\circ} \pm 15^{\circ}$ in southern Peru and $29^{\circ} \pm 19^{\circ}$ in northern Chile [Roperch et al., 2006; Arriagada et al., 2006; Taylor et al., 2005, 2007, and references therein], have been found to surpass the predictions of Isacks [1988] and Kley [1999] as well as to be older than Neogene.

[7] In this paper we investigate the processes leading to the formation of the Bolivian Orocline by a method of restoration in 2-D map view, which involves least squares numerical fitting of fault-bounded blocks [Audibert, 1991; Rouby et al., 1993; Bourgeois et al., 1997]. We first restore the deformation for the last $\sim 15 \mathrm{Ma}$, and then we produced two end-members of deformation models in the time interval $\sim 15-45 \mathrm{Ma}$. Our analysis of the geodynamic evolution of the Bolivian Orocline covers the Andes of central Peru to the Sierras Pampeanas and central Chile. The large scale of the study area and the lack of detailed and continuously distributed geological information impede a high-resolution map view restoration like those previously published by
Bourgeois et al. [1997] and Affolter and Gratier [2004] for other arcuate fold and thrust belts. Our main objective is to explore the amount and distribution of tectonic shortening along the strike of the central Andes and to provide firstorder constraints on the amount of pre-Neogene tectonic shortening that is needed to account for the CARP.

\section{Block Rotations and Paleogene Tectonics in the Central Andes}

[8] Recent paleomagnetic studies in southern Peru and northern Chile [Arriagada et al., 2006; Roperch et al., 2006; Taylor et al., 2007] have found no age-dependent differences in the magnitude of block rotations for Mesozoic and Paleogene rocks. Additionally, Somoza et al. [1999], Arriagada et al. [2006], and Roperch et al. [2006] found that rotations in Miocene or younger rocks $(<18-11 \mathrm{Ma}$ in northern Chile $<20 \mathrm{Ma}$ in southern Peru) are almost negligible, suggesting that most of the CARP was acquired during a single Paleogene episode of deformation. Taylor et 
al. [2007] suggested that this event occurred between 60 and $40 \mathrm{Ma}$. However, Roperch et al. [2006] found that late Eocene to early Oligocene red bed fore-arc deposits in southern Peru also record large (counterclockwise) rotations, suggesting that most of the fore-arc rotations were acquired between circa 45 and $25 \mathrm{Ma}$, when compressional or transpressional events affected large tracts of the central Andes (the "Incaic" event of Steinmann [1929]).

[9] Incaic deformation seems to have concentrated along discrete zones of crustal weakness at the edges of the Altiplano-Puna plateau: the Chilean Precordillera [Tomlinson et al., 1993; Maksaev and Zentilli, 1999; Mpodozis et al., 2005], the Eastern Cordillera of southern Peru [Carlotto, 1998; Sempere et al., 2002a], Bolivia [Roeder, 1988; Sheffels, 1990], and northwestern Argentina [Coutand et al., 2001; Oncken et al., 2006; Hongn et al., 2007; Ege et al., 2007, and references therein]. Whereas the Chilean Precordillera coincides with the thermally weakened Eocene to early Oligocene arc front, the Eastern Cordillera is an inherited mechanically weak zone, where more than $10 \mathrm{~km}$ of marine terrigenous sediment accumulated during the Paleozoic over a highly attenuated continental crust [Sempere et al., 2002b; Müller et al., 2002; Kley et al., 2005]. Deformation in the Chilean Precordillera began in the Late Cretaceous [Mpodozis et al., 2005, and references therein] and peaked during the Incaic event (45 to $\sim 32 \mathrm{Ma}$ ), when transpressional deformation, thickskinned thrusting, uplift, and crustal thickening all concentrated in a narrow belt, more than $1000 \mathrm{~km}$ long, between latitudes $29^{\circ} \mathrm{S}$ and $19^{\circ} \mathrm{S}$ [Maksaev and Zentilli, 1999]. Nevertheless, structures identified on detailed geological maps of northern Chile have been interpreted as accommodating no more than $20-30 \mathrm{~km}$ of Late Cretaceous to Paleogene shortening [e.g., Tomlinson et al., 1993].

[10] In contrast, significantly larger magnitudes of shortening have accumulated in the Eastern Cordillera [McQuarrie and DeCelles, 2001; Müller et al., 2002; McQuarrie, 2002b]. This occurred mainly in the PaleogeneEarly Miocene, starting at $\sim 45-40$ Ma [Barnes et al., 2006, 2008; Gillis et al., 2006; Ege et al., 2007], although preAndean deformation also is recorded by the Devonian and Ordovician strata.

[11] Müller et al. [2002] indicate that a thorough determination of Andean-age shortening within the Eastern Cordillera was delayed because the Ordovician succession which dominates the Eastern Cordillera in southern Bolivia is very thick and monotonous and was partially deformed prior to the Andean orogeny and because outcrops of Cretaceous and Tertiary strata are scarce. While Elger et al. [2005] indicate that the rate of shortening in the Eastern Cordillera peaked at $8 \mathrm{~mm} / \mathrm{a}$ during the late Oligocene, Horton [2005] found that large-scale upper crustal shortening $(60-140 \mathrm{~km})$ over large parts of the Eastern Cordillera (EC) was accomplished prior to 25-21 Ma because lower Miocene deposits in intermontane basins were deposited over highly deformed Ordovician to lower Paleogene rocks. McQuarrie et al. [2008] indicate that the highest magnitudes of shortening $(123 \mathrm{~km}$ or $55 \%)$ are in the EC. In the $\mathrm{EC}$, the amount of shortening appears to decrease progres- sively toward the north [Kley and Monaldi, 1998] as the Early Paleozoic sequences become thinner and toward the south as the sedimentary strata give way to the stronger Precambrian metamorphic rocks and Ordovician granitoids of northwestern Argentina [Kley et al., 2005]. McQuarrie et al. [2005] hypothesized that a basement thrust propagated eastward at $\sim 40 \mathrm{Ma}$, when the deformation front jumped almost $400 \mathrm{~km}$, from the thermally weakened Chilean Precordillera to the Eastern Cordillera. Long-distance propagation of deformation into the foreland has occurred recently in the Pampean flat slab segment of the Andes, giving credence to the idea of James and Sacks [1999] about a flat slab below the central Andes during the Eocene.

\section{Restoration}

\subsection{Methods and Data}

[12] Our method of 2-D map restoration is based on the removal of the horizontal components of slip on faults bounding tectonic blocks (fault heaves) by least squares minimization of interblock gaps and overlaps [Audibert, 1991; Rouby et al., 1993; Bourgeois et al., 1997]. To cope with the complexities of Andean tectonic style, we have modified the restoration algorithm to allow progressive unstraining of the blocks. We assume that the initial direction of shortening is orthogonal to the main fold axes and thrusts within each block and that it rotates with the block during the restoration. In most cases, the longest side of the block is parallel to the faults or fold axis, and the block is unstrained along an orthogonal direction. There is no change in the length of the block along strike during the restoration. In the original restoration method, the final shapes of the blocks were known. In the modified method, all the blocks to be undeformed and/or rotated are progressively unstrained (unshortened) in 30 or 60 steps and, after each step, the restoration minimizes the gaps and overlaps. This approach proves to be numerically more stable than if the blocks were fully unstrained first in a single step and then were restored with least squares minimization of interblock gaps and overlaps.

[13] Rotations are specified for some blocks, whereas others are allowed to rotate freely. Tectonic rotations within the Andes are numerous but are not uniformly distributed. To obtain a more coherent restoration, some of the rotation values used in the restoration were estimated on the basis of trends in the paleomagnetic data (Figure 1). In deformed areas where wrenching is important, large deviations in paleomagnetic directions are likely. Several of the largest rotations reported in the eastern domain of the central Andes (Puna, Eastern Cordillera, and Altiplano) occur within complex structures. Because these rotations may be restricted to the upper crust, they may not be fully representative of the CARP, and, therefore, we did not use them as constraints in the restoration. In contrast, along the fore arc, the results are more numerous and have often been obtained on subhorizontal strata. In Figure 1, we can recognize a welldefined trend of counterclockwise rotations along the fore arc of Peru and clockwise rotations along the Chilean fore arc. The main value of the paleomagnetic data is that it 

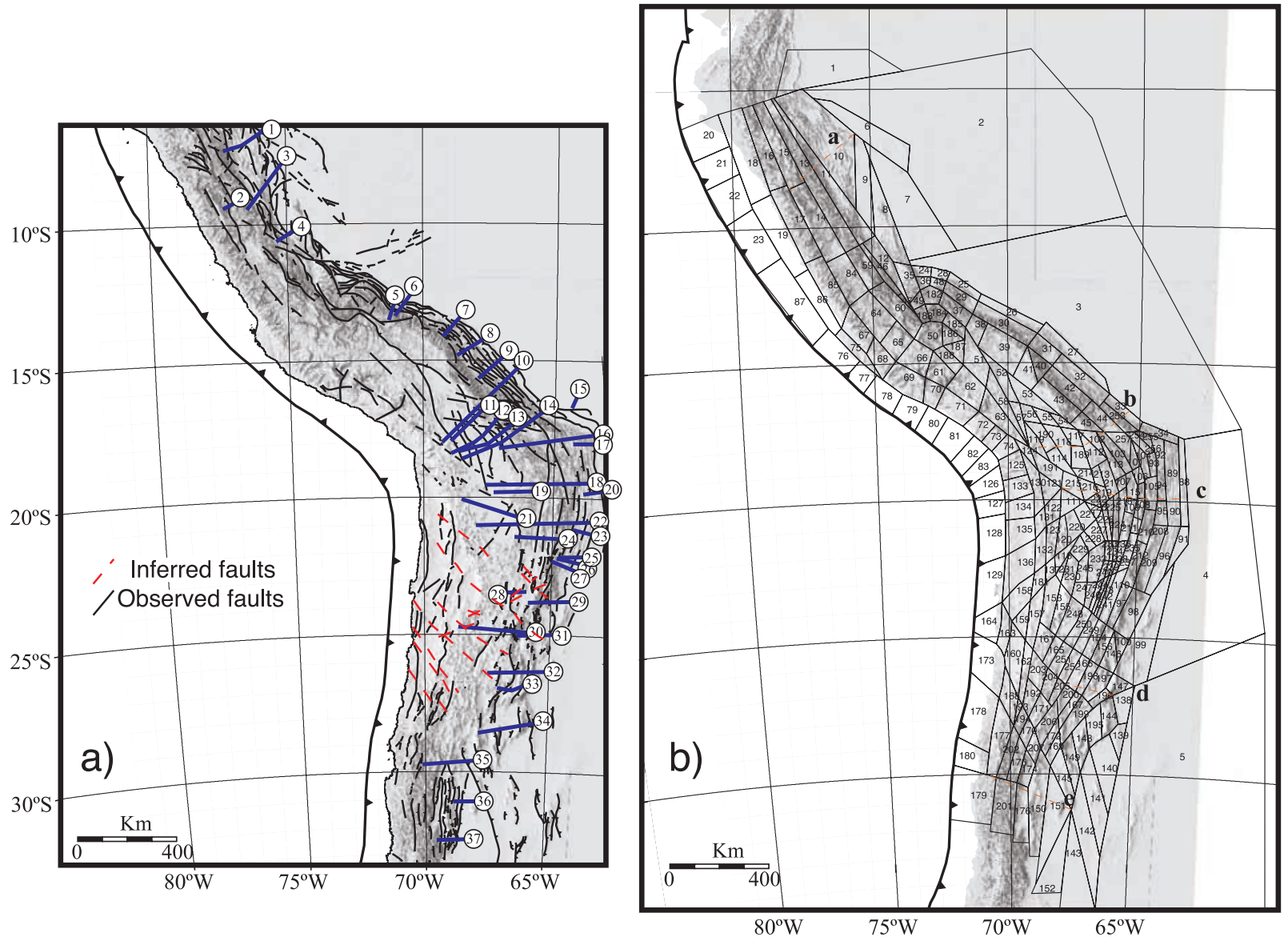

Figure 2. (a) Main structural features and data sources for shortening estimations used in the block model. The main observed faults come from maps from the geological surveys of Argentina, Bolivia, Chile, and Peru. The inferred faults are from Abels and Bischoff [1999] and Riller et al. [2001]. (b) Block model with the 257 blocks used in this study plotted on top of the shaded topography. The western border of the model corresponds to the trench. The red dashed lines correspond to the five examples of sections where the amount of shortening in the models is calculated in $\mathrm{km}$ to be compared with the published values (Table 1).

provides time constraints, large rotations occurring mainly in the Paleogene.

\subsection{Structural Map and Block Model}

[14] In his model of the central Andes $\left(\sim 15^{\circ} \mathrm{S}-25^{\circ} \mathrm{S}\right)$, Kley [1999] used 24 blocks. Baby et al. [1993] restored the deformation of the Santa Cruz belt within the sub-Andean zone using more than 70 blocks. Lamb [2000] used a continuum approach with a network of 26 triangles spanning the Bolivian Andes. In the map view kinematic model of Kley [1999], the fore arc, arc, and Altiplano-Puna domains were represented by only three large blocks: the largest clockwise rotation was mainly achieved by simple shear, the south Peruvian fore arc rotated counterclockwise by only $8^{\circ}$, and the fore arc did not bend.

[15] In contrast, our 2-D block map of the central Andes between $5^{\circ}$ and $30^{\circ} \mathrm{S}$ includes 257 fault-bounded blocks (Figure 2b). The map view structural model covers a larger area than models previously published [Baby et al., 1993; Kley, 1999] and includes the Andes of northern Peru and the southern central Andes of central Chile and the Argentine Precordillera. Our discontinuous approach and especially the number of blocks and the choice of the block-bounding faults are, of course, not unique. However, we have tried to include most of the major known structures of the Andes. Although the Altiplano and Puna have probably been subject to simple shear, we think that the fore arc, which is presently a rigid geotectonic element [Tassara, 2005], is best described as a set of rigid blocks. In this case, the spatial variations in the magnitude of rotation within the fore arc are more easily modeled with numerous small blocks.

[16] For the construction of the block model we first defined the most important regional faults (Figure 2a). Faults and folds are very obvious in the Eastern Cordillera and sub-Andean zone [Baby et al., 1989; Müller et al., 2002; McQuarrie, 2002b], where the major structures are 
Table 1. Comparison of the Published Geological Determination of Shortening for the Five Examples of Cross Sections Shown in Figure 2 and Shortening Data Used in the Models ${ }^{\mathrm{a}}$

\begin{tabular}{|c|c|c|c|c|c|c|c|c|c|}
\hline \multirow[b]{2}{*}{ Section } & \multirow[b]{2}{*}{ Length $^{\mathrm{b}}$} & \multicolumn{2}{|c|}{$0-15 \mathrm{Ma}$} & \multicolumn{3}{|c|}{$15-45 \mathrm{Ma}$} & \multicolumn{3}{|c|}{$0-45 \mathrm{Ma}$} \\
\hline & & $\begin{array}{c}\text { Geological } \\
\text { Determination }\end{array}$ & Model & $\begin{array}{c}\text { Geological } \\
\text { Determination }\end{array}$ & Model A & Model B & $\begin{array}{c}\text { Geological } \\
\text { Determination }\end{array}$ & Model A & Model B \\
\hline $\mathrm{a}$ & 350 & $20-84$ & 55 & $\sim 100$ & 15 & 55 & $\sim 150 \pm 30$ & 70 & 110 \\
\hline $\mathrm{b}$ & 450 & $72-135$ & 135 & $103-228$ & 60 & 270 & $\sim 175-350$ & 195 & 405 \\
\hline $\mathrm{c}$ & 520 & $30-110$ & 130 & $77-259$ & 55 & 240 & $\sim 100-360$ & 185 & 370 \\
\hline d & 200 & $15-70$ & 55 & & 30 & 75 & & 85 & 130 \\
\hline $\mathrm{e}$ & 365 & $10-117$ & 40 & & 10 & 30 & & 50 & 70 \\
\hline
\end{tabular}

${ }^{\mathrm{a}}$ Shortening is in $\mathrm{km}$.

${ }^{\mathrm{b}}$ Length is actual length of the sections.

roughly parallel to the margin. In contrast, to the west of the Eastern Cordillera, relatively few faults are evident on both geological maps and satellite images. The main structural features in the modern fore arc are linked to the $\mathrm{N}-\mathrm{S}$ trending Atacama and Domeyko fault system in northern Chile [Maksaev and Zentilli, 1999; Reutter et al., 1996; Tomlinson and Blanco, 1997; González et al., 2006] and to NW-SE trending faults in southern Peru [Sempere et al., 2002b; Roperch et al., 2006]. The northern part of the Bolivian Altiplano is dominated by the broad Corque syncline [Lamb and Hoke, 1997], whereas the structural fabric in the central portion of the Altiplano is dominated by NW-SE trending faults, and the southern Altiplano is crossed by a major northeast striking structural element known as the Uyuni-Khenayani fault zone [Sempere et al., 1990; Elger et al., 2005].

[17] Subsequently, the structural map was divided into blocks whose long sides coincided with fault or fold axis traces and whose short sides were roughly parallel to local shortening directions (Figure 2b). The largest elongate blocks were subdivided into small elements to facilitate block rotation during restoration and to take into account the gradients in regional shortening. Some of the block boundaries in the fore arc coincided with pronounced topographic features, such as the deep canyons of southern Peru and northern Chile. These have been interpreted as possible boundaries between domains that have different geological histories [Arriagada et al., 2003; Roperch et al., 2006]. Also, a few of the block boundaries in the southern part of the orocline (Puna plateau and Chilean fore arc) coincided with long NW-SE trending structural corridors or transAndean structures that have been described before [e.g., Abels and Bischoff, 1999; Riller et al., 2001; Richards and Villeneuve, 2002]. In the construction of the block model, some areas of wrenching along complex transfer zones (for example, the Abancay deflection and the CochabambaSanta Cruz fault zone) were, at the scale of this study, difficult to take into account. Also, in the southern part of the orocline, blocks are rhomb-shaped domains [Riller and Oncken, 2003], and shortening decreases with distance toward the central bend of the Andes. Our preferred block model, showing minimal gaps and overlaps in the restored state, was obtained after a trial-and-error procedure, during which the number and shapes of the blocks were progressively modified.

\subsection{Shortening}

[18] Shortening estimates and paleomagnetic data are now more numerous than they were when Kley [1999] and Lamb [2000] attempted to restore the central Andes. To run the 2-D map view restoration, we have taken advantage of geological information from published balanced cross sections (Figure 2a). For blocks without structural data, we have estimated the magnitudes of shortening using data from nearby blocks (Table 1). These estimates allowed us to run a more continuous and homogeneous restoration. Accurate estimates of shortening based on seismic data are available only for the sub-Andean belt where most of the mid-Neogene to present deformation has occurred. For this reason, the model of shortening for the time interval $0-15 \mathrm{Ma}$ is probably robust (shortening model $\mathrm{S}_{0-15}$, Figure $3 \mathrm{a}$ ). In contrast, as Paleogene shortening data are scarce and mainly from the central part of the orocline, we tested two extreme models of Paleogene deformation: one with small to moderate shortening (shortening model $\mathrm{S}_{15-45} \mathrm{~A}$, Figure $4 \mathrm{a}$ ) and the other with larger shortening (shortening model $\mathrm{S}_{15-45} \mathrm{~B}$, Figure $4 \mathrm{~b}$ ). The magnitudes of shortening used to perform the restorations are shown in the Table S1 in the auxiliary material. ${ }^{1}$

\subsection{Time Interval $0-15 \mathrm{Ma}$}

[19] During the first stage, the 2-D map view restoration removed mid-Miocene to Recent deformation (model $\mathrm{S}_{0_{-1}}$, Figure 3a). The blocks were progressively unstrained and rotated in 30 steps. In between each step of deformation, progressive least squares minimization of gaps and overlaps was performed in 40 steps. The completely unstrained and block-rotated restoration was thus obtained after 1200 iterations. Nevertheless, a further set of 200 iterations was performed. During this final stage, the blocks which had been previously constrained to rotate by $R$ (Figure $3 \mathrm{~b}$ ) were allowed to rotate freely within an interval $\pm \partial R$ arbitrarily set to $5^{\circ}$ or $10^{\circ}$ in order to further minimize gaps and overlaps.

\footnotetext{
${ }^{1}$ Auxiliary materials are available in the HTML. doi:10.1029/ 2008 TC002269.
} 


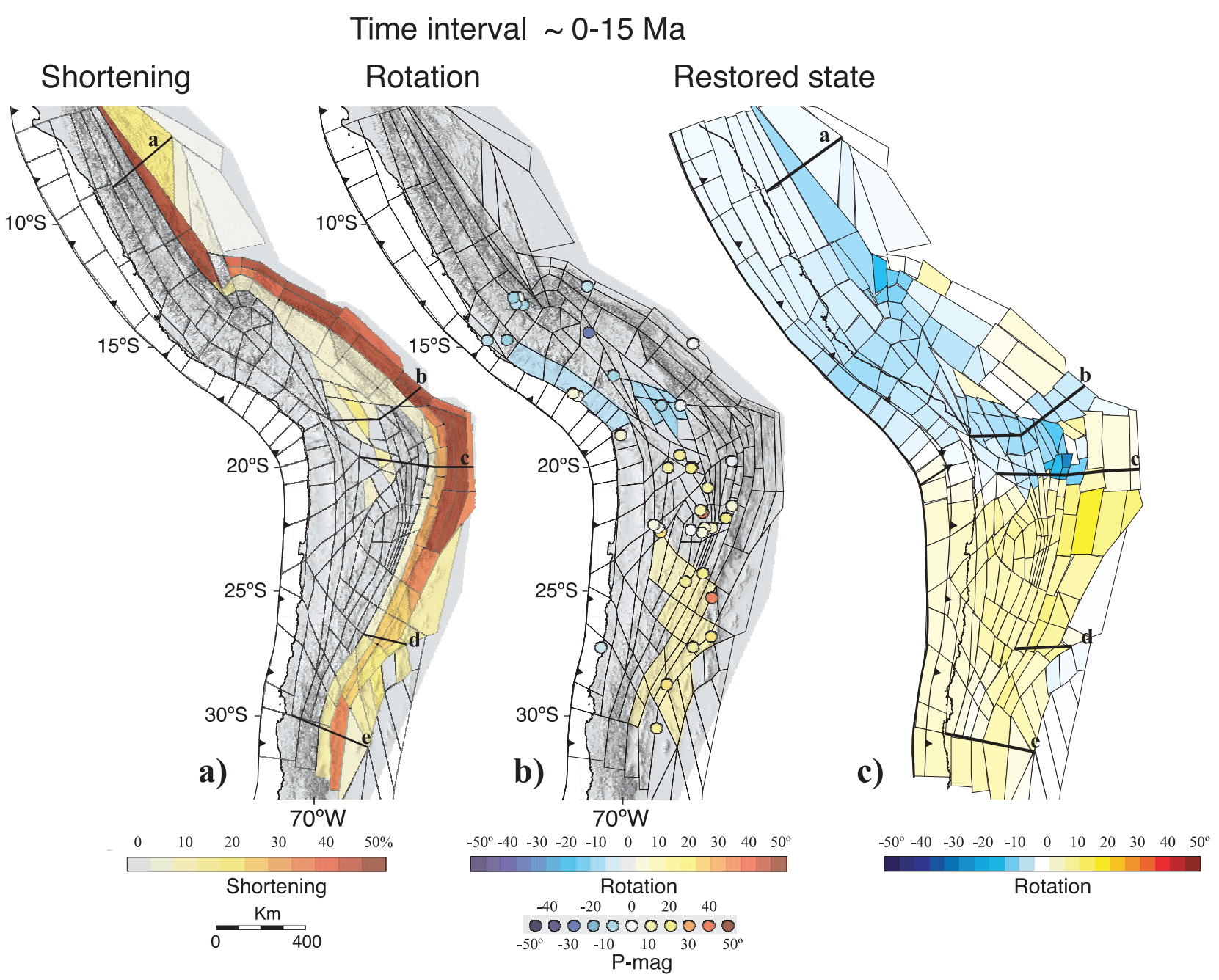

Figure 3. (a) Shortening model $\left(\mathrm{S}_{0-15}\right)$ for the mid-Miocene to Recent deformation. (b) Rotation values used to constrain the restoration between 0 and $15 \mathrm{Ma}$. For this model blocks were constrained to rotate by values $R$ (colored blocks) in the initial steps of the restoration and were free to rotate during the last 200 steps of the restoration within an interval of $\pm 5^{\circ}$ or $\pm 10^{\circ}$. For the first stage a trend of clockwise rotation was given for several blocks in the Puna. Within the northern Altiplano, the blocks chosen to rotate correspond roughly to the Corque syncline where a counterclockwise rotation is well defined. The other blocks are from the Peruvian fore arc where the counterclockwise rotations are minimum. (c) Twodimensional map view restoration $\mathrm{R}_{0-15}$. Colors indicate rotations of each block during restoration. Arrow illustrates total displacement of $\sim 140 \mathrm{~km}$ in the center of the orocline.

[20] Estimates of mid-Miocene to Pliocene shortening for the sub-Andean belt are relatively well established from numerous seismic lines acquired by the petroleum industry (Figure 2a and auxiliary material). The most recent compilations of the magnitudes of crustal shortening along the central Andes [Oncken et al., 2006] consider that crustal shortening is concentrated in the Bolivian Andes. However, the few studies available for the Peruvian foreland [Gil Rodriguez et al., 2001; Hermoza et al., 2005] indicate shortening from $121 \mathrm{~km}$ at $\sim 13^{\circ} \mathrm{S}$ to $84 \mathrm{~km}$ at $\sim 7^{\circ} \mathrm{S}$. In the southern central Andes near San Juan and Mendoza in Argentina, shortening magnitudes $>100 \mathrm{~km}$ have also been reported [Allmendinger et al., 1990; Ramos et al., 1996].
These relatively high values of shortening suggest that the along-strike gradient in shortening may be less than previously accepted for the mid-Miocene to Recent.

[21] During restoration the blocks were unstrained along a direction orthogonal to the strike of the major thrusts and fold belts. The amount of shortening attributed to each block was chosen to be in the range indicated by geological cross sections, while an along-strike gradient of shortening was included in order to respect the regional trends in the available shortening data. A trend of clockwise rotation was given for several blocks in the Puna, where small clockwise rotations have been reported [Coutand et al., 1999] (Figure 3b). Within the northern Altiplano, the blocks 


\section{Time Interval 15-45 Ma}

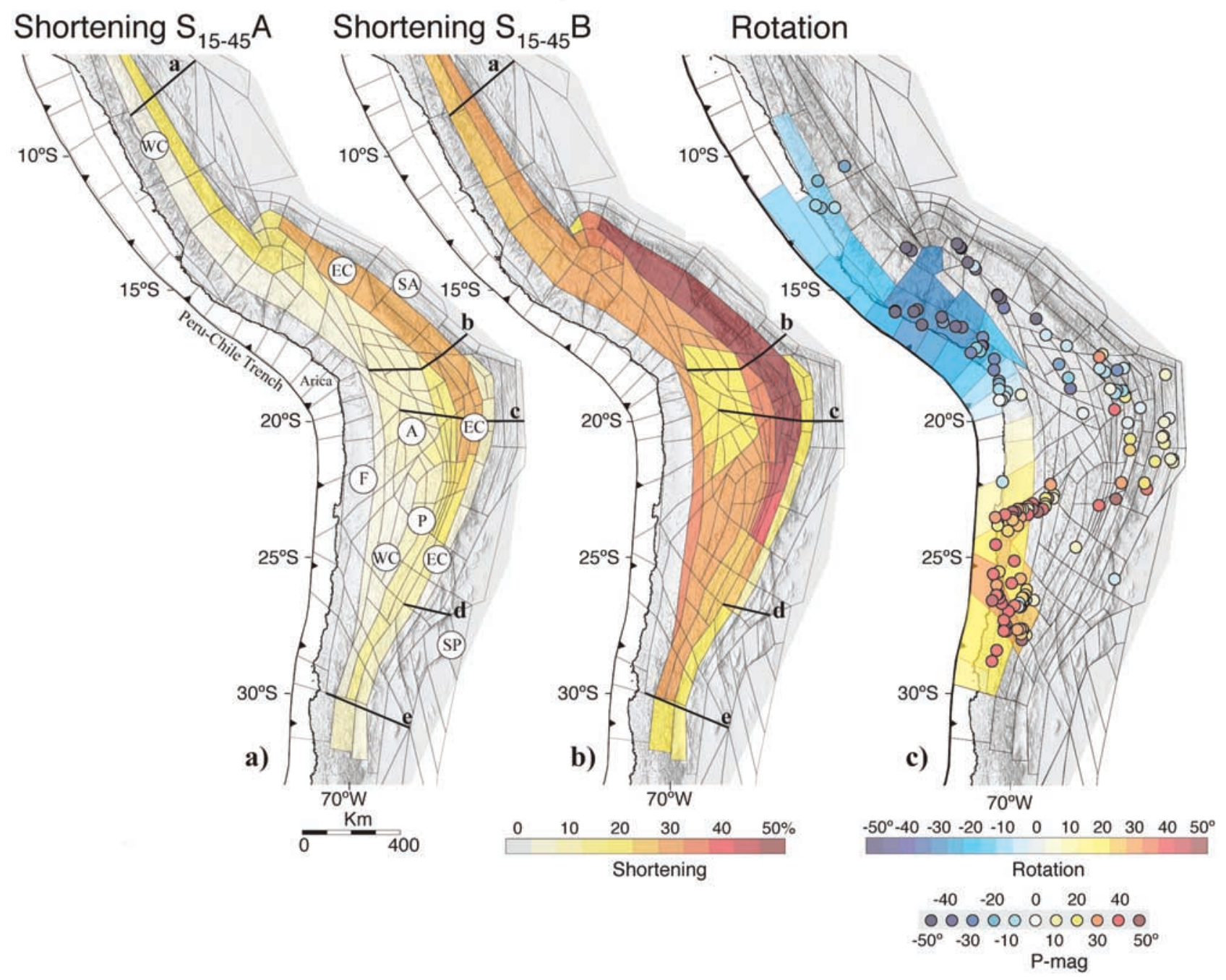

Figure 4. Two shortening models $\left(\mathrm{S}_{15-45} \mathrm{~A}\right.$ and $\left.\mathrm{S}_{15-45} \mathrm{~B}\right)$ for the Eocene to Miocene are shown. Maximum value of shortening in the Eastern Cordillera is (a) $30 \%$ (model $\mathrm{S}_{15-45} \mathrm{~A}$ ) and (b) $55 \%$ (model $\left.\mathrm{S}_{15-45} \mathrm{~B}\right)$. (c) For the restorations constrained with rotation $\left(\mathrm{R}_{0-45} \mathrm{~A}_{\mathrm{wr}}\right.$ and $\left.\mathrm{R}_{0-45} \mathrm{~B}_{\mathrm{wr}}\right)$ the colored blocks were forced to rotate by the values shown (with $\partial R$ set to only $1^{\circ}$ ). The blocks forced to rotate correspond to those from the fore arc where the paleomagnetic data are numerous. Again, the choice does respect the trend of rotations observed in the paleomagnetic data, especially the large rotations observed in southern Peru and in Chile between $23^{\circ}$ and $27^{\circ} \mathrm{S}$. The choice of the blocks with rotation constraints is slightly arbitrary but enables a more homogeneous restoration.

chosen for rotation correspond roughly to the Corque syncline, where a counterclockwise rotation is well defined [Roperch et al., 1999]. The other blocks are from the Peruvian fore arc, where $5^{\circ}-10^{\circ}$ of counterclockwise rotation have been reported [Rousse et al., 2003].

[22] The 2-D map view restoration $\left(\mathrm{R}_{0-15}\right.$, Figure $\left.3 \mathrm{c}\right)$ was obtained after removal of mid-Neogene to late Neogene shortening, mainly in the sub-Andean zone. It depicts no major changes in shape of the continental margin. Near Arica, the reference line of the Peru-Chile trench axis is displaced $140 \mathrm{~km}$ to the west of its current position (Figure 3c). The calculated values of rotation are small (less than $10^{\circ}$, Figure $3 \mathrm{c}$ ) and consistent with both the measured values $\left(<10^{\circ}\right)$ [Somoza et al., 1999; Barke et al., 2007] and the predicted values $\left(5^{\circ}-15^{\circ}\right)$ [Isacks, 1988].

\subsection{Time Interval $15-45$ Ma}

[23] Two different models of shortening $\left(\mathrm{S}_{15-45} \mathrm{~A}\right.$ or $\mathrm{S}_{15-45} \mathrm{~B}$ ) for the Eocene to mid-Miocene interval were tested during the second restoration stage (Figures $4 \mathrm{a}$ and $4 \mathrm{~b}$ ). Both models of shortening were restored with or without rotation constraints. For the Paleogene restoration, the initial block model was the one restored to $15 \mathrm{Ma}$. The blocks were unstrained and rotated in 40 steps. In between each step of 


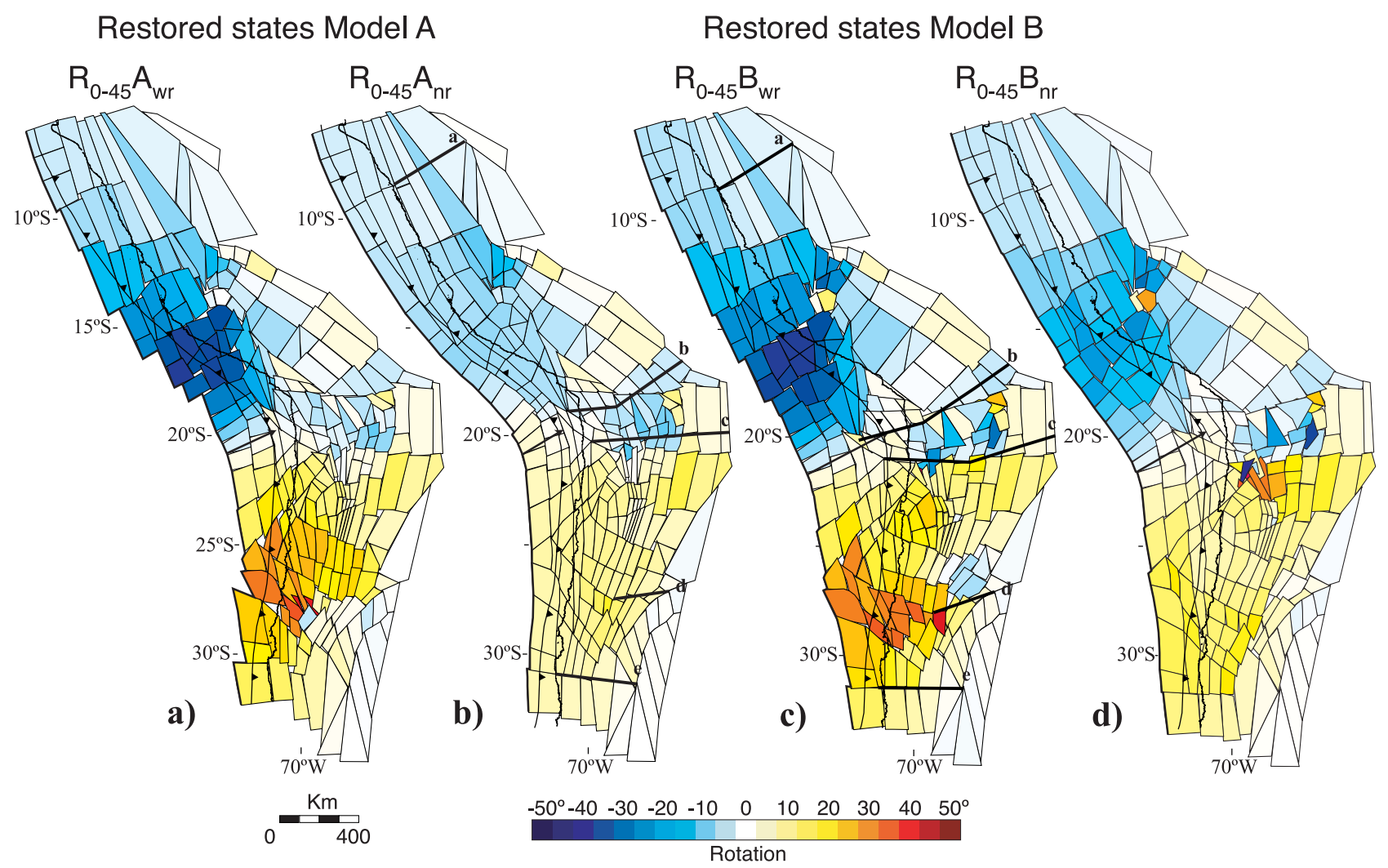

Figure 5. Two-dimensional map view restorations of the central Andes using the shortening models $\mathrm{S}_{15-45} \mathrm{~A}$ and $\mathrm{S}_{15-45} \mathrm{~B}$. Colors indicate rotations of each block during restoration. (a) Restored map for model with constrained block rotations $\left(\mathrm{R}_{0-15} \mathrm{~A}_{\mathrm{wr}}\right)$. (b) Same as Figure 5a but without rotation constraints $\left(\mathrm{R}_{0-45} \mathrm{~A}_{\mathrm{nr}}\right)$. Arrow illustrates total displacement of $\sim 210 \mathrm{~km}$ in the center of the orocline. (c) Restored map for model with constrained block rotations $\left(\mathrm{R}_{0-45} \mathrm{~B}_{\mathrm{wr}}\right)$. (d) Same as Figure $5 \mathrm{c}$, but the blocks were allowed to rotate freely during the last stages of the restoration $\left(\mathrm{R}_{0-45} \mathrm{~B}_{\mathrm{nr}}\right)$. Arrow illustrates total displacement of $\sim 430 \mathrm{~km}$ in the center of the orocline.

deformation, minimization of gaps and overlaps required 60 steps. The completely unstrained and block-rotated model (15-45 Ma) was thus obtained after 2400 iterations. Nevertheless, a further set of 600 iterations was performed. The blocks that were forced to rotate were in the fore arc (Figure 4c). The chosen values respect the trend of rotations observed in the paleomagnetic data, especially the large rotations observed in southern Peru and in Chile between $23^{\circ}$ and $27^{\circ} \mathrm{S}$.

3.5.1. Restoration With Low Shortening (Model A)

[24] In model $\mathrm{S}_{15-45} \mathrm{~A}$ (Figure $4 \mathrm{a}$ ), the amount of Paleogene shortening was the smallest available (28\% shortening in the Eastern Cordillera). Apart from the early work of Mégard [1984], there is no estimate of shortening in the Peruvian Andes, excluding the sub-Andean belt. Wellestablished shortening values are also missing or incomplete for the Western Cordillera and most of the Puna plateau.

[25] The restoration was done either with rotation constraints $\left(\mathrm{R}_{0-45} \mathrm{~A}_{\mathrm{wr}}\right)$ or with no rotation constraints $\left(\mathrm{R}_{0-45} \mathrm{~A}_{\mathrm{nr}}\right)$. Eocene-Oligocene shortening in the Eastern Cordillera is $\sim 50-60 \mathrm{~km}$, over and above the $\sim 130-140 \mathrm{~km}$ of maximum shortening for the first stage. The total shortening of $\sim 200 \mathrm{~km}$ is in line with the estimate of $191 \mathrm{~km}$ by Baby et al. [1997].

[26] In restoration $\mathrm{R}_{0-45} \mathrm{~A}_{\mathrm{nr}}$ (Figure 5b), the fore arc behaved like a homogeneous rigid body during the restoration because the arrangement of the blocks along the margin was initially very tight. This model provides a lower limit on the amount of rotation along the margin driven by shortening in the back arc. Unbending of the margin is limited, and the calculated rotations are much smaller than those actually measured by paleomagnetic studies (Figure 1).

[27] In restoration $\mathrm{R}_{0-45} \mathrm{~A}_{\mathrm{wr}}$ (Figure 5a), blocks were constrained to rotate by $R$, and $\partial R$ was set to only $\pm 1^{\circ}$ so as to prevent the blocks from unrotating during the final stage of the restoration. The restored fault block map (Figure 5a) shows considerable geological discontinuities along the western margin, contradicting the observed continuity of the Mesozoic and Cenozoic arcs.

\subsubsection{Restoration With High Shortening (Model B)}

[28] The maximum of Eocene-Oligocene shortening was set to $55 \%$ and was focused in the Eastern Cordillera of Bolivia and southern Peru. We also considered significant Paleogene compressional deformation in the northern Alti- 

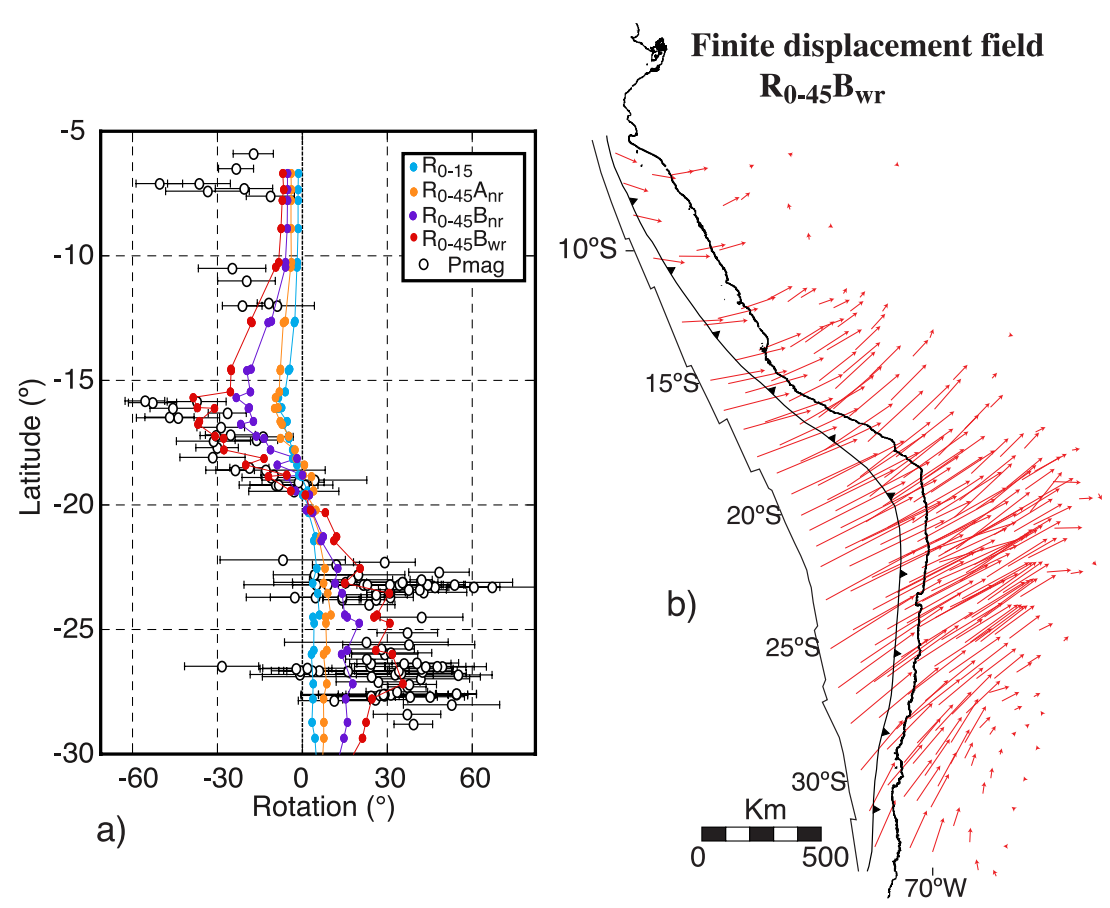

Figure 6. (a) Comparison of paleomagnetic rotations (open circles with error bars) observed along the fore arc with those calculated for 41 blocks in the different restorations. (b) Total (Paleogene to present) displacement vectors for restoration $\mathrm{R}_{0-45} \mathrm{~B}_{\mathrm{wr}}$.

plano, part of the Puna, and the Precordillera of Chile, where shortening values were set to $\sim 30 \%$ despite the lack of good estimates (Figure $4 \mathrm{~b}$ ). The final restorations implied a total shortening of about $400 \mathrm{~km}$. In one restoration $\left(\mathrm{R}_{0-45} \mathrm{~B}_{\mathrm{wr}}\right.$, Figure 5c), the rotation constraints were as in model $\mathrm{R}_{0-45} \mathrm{~A}_{\mathrm{wr}}$ (Figure $4 \mathrm{c}$ ). In the other restoration, the blocks were forced to rotate as in model $\mathrm{R}_{0-45} \mathrm{~A}_{\mathrm{wr}}$ but were free to do so during the final stage $\left(\mathrm{R}_{0-45} \mathrm{~B}_{\mathrm{nr}}\right)$. In Figure $5 \mathrm{~d}$, we can recognize that the release of the rotation constraint in restoration $\mathrm{R}_{0-45} \mathrm{~B}_{\mathrm{nr}}$ let most of the blocks unrotate partly with respect to restoration $\mathrm{R}_{0-45} \mathrm{~B}_{\mathrm{wr}}$ (Figure $5 \mathrm{c}$ ).

[29] The restoration with large shortening and large rotation $\left(\mathrm{R}_{0-45} \mathrm{~B}_{\mathrm{wr}}\right.$, Figure $\left.5 \mathrm{c}\right)$ yielded a more continuous and straighter margin than the restoration in model $\mathrm{R}_{0-45} \mathrm{~A}_{\mathrm{wr}}$ (Figure 5a). The restoration with the blocks allowed to rotate freely during the final stage of the restoration $\left(\mathrm{R}_{0-45} \mathrm{~B}_{\mathrm{nr}}\right.$, Figure 5d) induced a minimum of $20^{\circ}$ of counterclockwise rotation in southern Peru and $15^{\circ}$ clockwise rotation in northern Chile along the fore arc. Displacement vectors for each block are almost orthogonal to the Paleogene margin at $18^{\circ} \mathrm{S}$, but the angle rapidly decreases southward. As shown in Figure 6b, bending of the margin seems to have been accompanied by a major component of orogen-parallel transport toward the symmetry axis of the Orocline.

[30] The complete history of restoration (model $\mathrm{R}_{0-45} \mathrm{~B}_{\mathrm{wr}}$ ) is illustrated by Animations 1 and 2 (rotation field and shortening). ${ }^{2}$ These animations allow also a better understanding of how the restorations are performed. In order to reduce the size of the files, the sequences are shown with

\footnotetext{
${ }^{2}$ Animations 1 and 2 are avaiable in the HTML. doi:10.1029/ 2008TC002269.
}

0.5 Ma increments. There is no attempt to constrain the rate of deformation, and a linear rate is used for both time intervals.

\subsection{Error Analysis}

[31] Errors in the restored models are illustrated in Figure 7. The restorations are visually satisfactory. In the restorations with important shortening, overlaps and localized strong rotations are observed near Cusco in southern Peru (blocks 183 and 184), in Cochabamba (block 255), and in southern Bolivia (blocks 232, 233, and 234). The small size of the blocks associated with a complex geometry of the deformation explains the anomalous behavior during the restoration (Figure $5 \mathrm{~d}$ ). The sum of the block overlaps after restoration is $\sim 3.6 \%$ of the final area in restoration $\mathrm{R}_{0-15}$ and $4.2 \%$ of the final area in model $\mathrm{R}_{0-45} \mathrm{~B}_{\mathrm{wr}}$. The sum of block gaps is $\sim 1 \%$ and $\sim 2 \%$ of the final area in the restored states $\mathrm{R}_{0-15}$ and $\mathrm{R}_{0-45} \mathrm{~B}_{\mathrm{wr}}$, respectively. The area increase during unstraining is $11 \%$ of the initial area for the restored state $\mathrm{R}_{0-15}, \sim 16 \%$ for restoration $\mathrm{R}_{0-45} \mathrm{~A}$, and $\sim 31 \%$ for restoration $\mathrm{R}_{0-45} \mathrm{~B}$.

\section{Discussion}

\subsection{Restoration of the Orocline}

[32] In the restored state $\mathrm{R}_{0-15}$, there is about $30-50 \mathrm{~km}$ more shortening than the foreland belt estimates of Oncken et al. [2006] (Figure 8). Our model better takes into account the largest shortening values reported for the Peruvian subAndean zone [Gil Rodriguez et al., 2001] and the Argentine Precordillera [Ramos et al., 1996]. Shortening in the sub- 


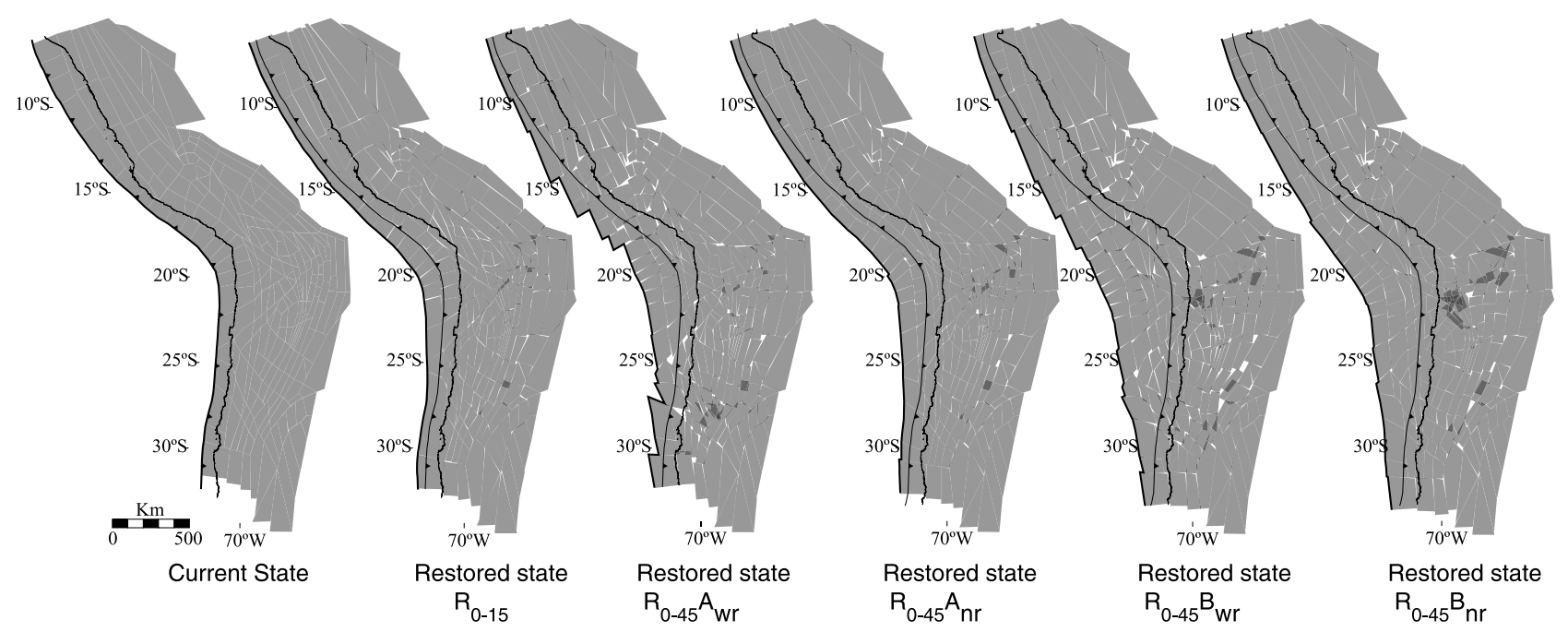

Figure 7. Misfit in the models. Overlaps are indicated by dark shading. White surfaces indicate gaps.

Andean zone was able to bend the continental margin by $5^{\circ}-7^{\circ}$, producing only a fraction (14-24\%) of the CARP.

[33] The second restoration with shortening model $\mathrm{S}_{15-45} \mathrm{~A}$ corresponds to $\sim 200 \mathrm{~km}$ of shortening, which is the lowerend estimate of total Andean shortening. Such a low amount of shortening seems incompatible with the observed CARP (Figure 6b). When the restoration is constrained by rotations $\left(\mathrm{R}_{0-15} \mathrm{~A}_{\mathrm{wr}}\right.$, Figure 5a), large in situ block rotations and segmentation of the fore arc are observed. However, there is no geological evidence for such a large segmentation of the Peruvian margin where late Eocene-Oligocene fore-arc deposits are not significantly deformed. Dextral partitioning during oblique convergence was proposed to explain clockwise rotations along the Chilean margin [Beck, 1998]. In such a model, counterclockwise rotations in Peru would imply sinistral margin-parallel displacements along the Peruvian margin, but these opposite displacements along Peruvian and Chilean margins are inhibited near Arica. Thus, there is no tectonic mechanism capable of producing the CARP by in situ rotations without significant bending.

[34] The large magnitude of the CARP is better explained by a largest amount of shortening in the central Andes during the Eocene-Oligocene [see also McQuarrie, 2002a]. Although the Eocene-Oligocene Incaic event was important in the Chilean Precordillera, the modest amount of horizontal shortening (no more than $30 \mathrm{~km}$ ) was of no major consequence for the formation of the Bolivian Orocline. Therefore, shortening needs to be searched for further east, either in the Altiplano-Puna or in the Eastern Cordillera. In the restored model $\mathrm{R}_{0-45} \mathrm{~B}_{\mathrm{wr}}$ shortening is up to $430 \mathrm{~km}$ and exceeds by $>100-150 \mathrm{~km}$ the maximum shortening proposed by Oncken et al. [2006] that is mostly concentrated in the central Bolivian Andes $\left(16^{\circ}-24^{\circ} \mathrm{S}\right)$ (Figure 8). The variations of shortening along strike in the restored model $\mathrm{R}_{0-45} \mathrm{~B}_{\mathrm{wr}}$ are, however, not very different from the equivalent shortening curve derived from crustal cross-sectional area, assuming that all crustal thickening is of tectonic origin [Isacks, 1988; Kley and Monaldi, 1998].

\subsection{Oroclinal Bending and In Situ Rotations}

[35] Even the large oroclinal bending associated with shortening model $\mathrm{S}_{0_{-} 5} \mathrm{~B}$ and observed in restoration $\mathrm{R}_{0_{-}}$ ${ }_{45} \mathrm{~B}_{\mathrm{nr}}$ does not fully explain the rotations seen in the paleomagnetic data (Figures 5 and $6 \mathrm{a}$ ), suggesting either even stronger oroclinal bending or the occurrence of secondary in situ block rotations in the same sense that are coupled to those induced by pure bending. With a large amount of total shortening, strike-slip displacements and wrenching are likely to occur during bending. Thus, we think that our upper end model of shortening $\left(\mathrm{S}_{15-45} \mathrm{~B}\right)$ is sufficient to explain the component of rotation purely driven by oroclinal bending (Figure 5d) and the additional component of in situ rotation of blocks associated with wrenching during bending (Figure 5c). In the present restorations, strike-slip displacements are difficult to take into account. Carlier et al. [2005] suggest a dextral transpressional regime imposed on two rigid lithospheric blocks in the southern Peruvian Altiplano, while left-lateral displacements have also been suggested for other fault systems in the Peruvian Altiplano [Rousse et al., 2005]. Left-lateral strike-slip displacement has been reported along the Cochabamba-Santa Cruz fault zone, which is presently active [Funning et al., 2005], and within the northern Chilean Precordillera during the late Oligocene-early Miocene [Reutter et al., 1996; Tomlinson and Blanco, 1997].

[36] In northern Chile, the main fault systems are $\mathrm{N}-\mathrm{S}$ trending structures, but the largest rotations occur between $23^{\circ}$ and $29^{\circ} \mathrm{S}$ along major obliquely trending lineaments [Arriagada et al., 2003; Taylor et al., 2007]. Our restoration with maximum shortening $\left(\mathrm{S}_{15-45} \mathrm{~B}\right)$ (Animations 1 and 2 ) shows that these obliquely trending structures rotate during the oroclinal bending in a bookshelf style, accommodating margin-wide shortening and an additional secondary component of local rotation [Abels and Bischoff, 1999; Taylor et al., 2005, 2007]. On the other hand, Riller and Oncken [2003] interpret the paleomagnetic rotations in terms of both 


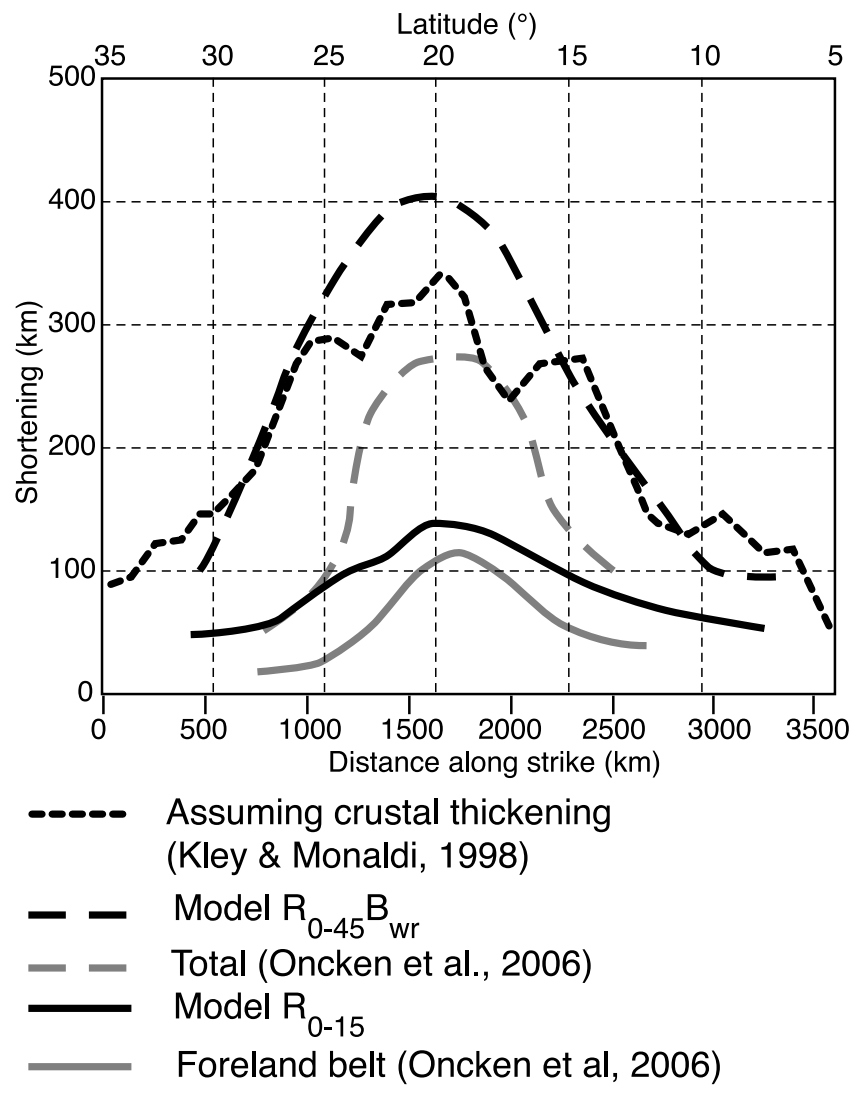

Figure 8. Variations of shortening along strike of central Andes. Thick dotted line is equivalent shortening curve derived from crustal-section area assuming that all crustal thickening is tectonic (modified from Kley and Monaldi [1998]). Thick line and thick dashed line are shortening in restoration $\mathrm{R}_{0-15}$ and restoration $\mathrm{R}_{0-45} \mathrm{~B}_{\mathrm{wr}}$, respectively. Thin line and thin dashed line are magnitudes of shortening for the foreland belt and total estimate, respectively (modified from Oncken et al. [2006]).

rigid and shear-induced rotations to explain Neogene deformation in the Puna. For a shortening of up to $400 \mathrm{~km}$, strike-slip displacements and shear-induced rotations are likely but not well quantified.

[37] The pattern of large counterclockwise rotations along the Peruvian margin suggests that the Abancay deflection, at the transition between the central Peruvian Andes and the southern Peruvian Andes, is the principal transfer zone inducing counterclockwise rotations. Geochemical data [Carlier et al., 2005; Mamani et al., 2008] show significant crustal and lithospheric heterogeneities in the central Andes and especially in southern Peru. Mamani et al. [2008] argue that the different rheologies are an important factor in controlling the deformation pattern of the central Andes and the localization of the Andean plateau. They suggest that most of the rotations are the results of intense shearing along the border of the Arequipa block. While the geochemical data suggest a sharp boundary between the Arequipa block and the central Peruvian
Andes, large rotations are not restricted but are observed in a much wider area north and south of the geochemical boundary.

\subsection{Margin-Parallel Extension and Mass Transfer}

[38] Hindle et al. [2005], using the map view kinematic model from Kley [1999], propose significant material transfer toward the center of the orocline to account for the difference between the low shortening estimates and the thick Andean crust (material displaced with along-trend component is $35-40 \%$ of material that moved normal to the trend of the mountain range). In our model, about 10 $15 \%$ of along-strike material transfer is observed. The displacement field shown in Figure $6 \mathrm{~b}$ suggests that the material balance is affected by along-strike motion of material essentially in the southern part of the orocline but not at its center.

[39] Bending of the margin was accompanied by $\sim 200 \mathrm{~km}$ of margin-parallel stretching ( $\sim 260 \mathrm{~km}$ for an initially straight margin). This extension may be distributed all along the margin, as internal deformation of the blocks, involving a minor latitudinal displacement. Extension associated with bending along the limbs of the orocline is also likely to facilitate in situ block rotations and may explain the differences between the observed rotations from paleomagnetic data and those observed in the model driven only by shortening (Figures 5c, 5d, and 6). In the numerical restorations, distributed along-strike extension is not taken into account, and large lateral displacements associated with bending are thus observed on both limits of the models in central Chile and northern Peru. Northward mass transfer in central Chile should imply a maximum displacement of about $150 \mathrm{~km}$ at $\sim 30^{\circ} \mathrm{S}$, while southward displacement of the northern Peruvian fore arc is about $50 \mathrm{~km}$ at $\sim 10^{\circ} \mathrm{S}$. Northward displacement of the fore arc in central Chile might have driven, at least in part, crustal thinning and the late Eocene-Oligocene extension documented south of $33^{\circ} \mathrm{S}$ [e.g., Jordan et al., 2001; Charrier et al., 2002]. The pattern of mass transfer is also consistent with deformation partitioning during the late Cenozoic in the Andean foreland of Argentina $\left(27^{\circ}-33^{\circ} \mathrm{S}\right)$ [de Urreiztieta et al., 1996; Siame et al., 2005] and is even observed in GPS data [Kendrick et al., 2006]. Consequently, the growth of the orocline by differential tectonic shortening might have driven processes of orogen-parallel stretching and displacement partitioning.

\subsection{Oroclinal Bending and Uplift}

[40] Our preferred model of restoration corresponds to large late Paleogene-early Miocene deformation and mountain building in the Andes. However, several recent studies have focused attention on a significant rise of the central Andes since $\sim 10$ Ma. Paleotemperature estimates derived from fossil leaf physiognomy suggest paleoelevations of no more than a third of the plateau's modern average height of $\sim 4 \mathrm{~km}$ at $\sim 15-20 \mathrm{Ma}$ [Gregory-Wodzicki, 2000], while recent oxygen isotope paleoaltimetry [Garzione et al., 2006] suggests surface uplift of $3 \pm 0.5 \mathrm{~km}$ between $\sim 10 \mathrm{Ma}$ and 6.8 Ma. Garzione et al. [2006] and Molnar and Garzione 
[2007] suggested that this major phase of uplift of the northern Bolivian Altiplano was the result of the removal of mantle lithosphere, including eclogitized lower crust, from beneath the region in that time interval. However, Hoke and Lamb [2007] interpret behind-arc mafic-felsic magmatism in the Altiplano and western margin of the Eastern Cordillera as evidence for an already thin lithospheric mantle beneath the Altiplano since circa $25 \mathrm{Ma}$ after a period of significant crustal shortening in the Altiplano and Eastern Cordillera occurred mainly between circa 40 and 30 Ma [Lamb and Hoke, 1997; Lamb et al., 1997; McQuarrie, 2002b]. Interpretation of paleoaltimetry data may also be very sensitive to changes in paleoclimate, and the hypothesis of a steady rise of the Andean Plateau since circa 40 Ma cannot be rejected [Ehlers and Poulsen, 2007].

\subsection{Building of the Andes and Sea Level Variation}

[41] Finally, and as a secondary result, by using the relative change in surface between the restored state $R_{0-}$ ${ }_{45} \mathrm{~B}_{\mathrm{wr}}$ and the initial block model in its current state $(\sim 31 \%)$, we have computed a surface loss of $\sim 750,000$ $\mathrm{km}^{2}$ for the South American Plate. If the mean depth of the oceans is $\sim 4 \mathrm{~km}$, about $7 \mathrm{~m}$ of global sea level fall occurred during the development of the Bolivian Orocline since the Eocene. Thus, plan view restorations in other segments of the Andes or collisional orogens of Cenozoic age could help to better constrain eustatic variations in sea level.

\section{Conclusions}

[42] By using first-order constraints on the magnitude and age of shortening and rotations in the central Andes, we have run a 2-D map view restoration experiment in order to explore the effects of tectonic shortening and tectonic rotations on the structural evolution of the Bolivian Oro- cline. Restoration is first performed to remove the deformation (0-15 Ma) mainly localized in the foreland belt, and two end-members of late Paleogene-early Miocene shortening are then explored. The following conclusions can be drawn from the present study.

[43] 1. Neogene shortening in the sub-Andean zone only slightly enhanced the orogenic curvature of the central Andes, which, for the most part, formed during the Paleogene.

[44] 2. The upper end model of total horizontal shortening (more than $400 \mathrm{~km}$ near the Arica bend) better explains the measured CARP. Although the magnitudes of the observed rotations exceed the component driven by pure bending, large bending is also likely to induce strike-slip displacements capable of producing an additional component of in situ rotations.

[45] 3. Results are consistent with the hypothesis that the Bolivian Orocline formed during the Eocene-Oligocene, as a consequence of differential horizontal shortening, essentially in the Eastern Cordillera.

[46] 4. Restoration results show that the Paleogene bending of the central Andean orogen was accompanied by a component of margin-parallel extension along the southern limb and/or orogen-parallel transport of material toward the symmetry axis of the orocline.

[47] 5. Large shortening and bending of the orocline led to a surface loss of $\sim 750,000 \mathrm{~km}^{2}$ for the South American Plate, resulting in about $7 \mathrm{~m}$ of global sea level fall since the Eocene.

[48] Acknowledgments. Funding for this study was provided by Fondecyt-Chile (grants 1050750 and 3030050) and IRD. We thank Delphine Rouby for her help during the initial stages of the work and for providing the numerical code for the restoration program. We are grateful for helpful reviews from two anonymous referees. N. McQuarrie, M. Beck, S. Lamb, and E. Sobel provided valuable criticism of an earlier version of the manuscript.

\section{References}

Abels, A., and L. Bischoff (1999), Clockwise block rotations in northern Chile: Indications for a large-scale domino mechanism during the middlelate Eocene, Geology, 27, 751-754, doi:10.1130/ 0091-7613(1999)027<0751:CBRINC >2.3.CO;2.

Affolter, T., and J. P. Gratier (2004), Map view retrodeformation of an arcuate fold-and-thrust belt: The Jura case, J. Geophys. Res., 109, B03404, doi:10.1029/2002JB002270.

Allmendinger, R. W., D. Figueroa, D. B. Snyder, J. Beer, C. Mpodozis, and B. L. Isacks (1990), Foreland shortening and crustal balancing in the Andes a $30^{\circ} \mathrm{S}$ latitude, Tectonics, 9, 789-809, doi:10.1029/ TC009i004p00789.

Allmendinger, R. W., R. Smalley, M. Bevis, H. Caprio, and B. A. Brooks (2005), Bending the Bolivian Orocline in real time, Geology, 33, 905-908, doi:10.1130/G21779.1.

Arriagada, C., P. Roperch, C. Mpodozis, G. DupontNivet, P. R. Cobbold, A. Chauvin, and J. Cortés (2003), Paleogene clockwise tectonic rotations in the forearc of central Andes, Antofagasta region, northern Chile, J. Geophys. Res., 108(B1), 2032, doi:10.1029/2001JB001598.

Arriagada, C., P. Roperch, C. Mpodozis, and R. Fernández (2006), Paleomagnetism and tectonics of the southern Atacama Desert $\left(25-28^{\circ} \mathrm{S}\right)$, northern Chile,
Tectonics, 25, TC4001, doi:10.1029/ 2005 TC001923.

Audibert, M. (1991), Déformation discontinue et rotations de blocs, méthodes numériques de restauration, in Mémoires et Documents du Centre Armoricain d'Etude Structurale des Socles, vol. 40, 239 pp., Géosci. Rennes, Rennes, France.

Baby, P., G. Herail, J. M. Lopez, J. Oller, J. Pareja, T. Sempere, and D. Tufiño (1989), Structure de la zone subandine de Bolivie: Influence de la géométrie de séries sédimentaires antéorogéniques antéorogéniques sur la propagation de chevauchements, $C$ R. Acad. Sci., Ser. II, 309, 1717-1722.

Baby, P., B. Guillier, J. Oller, and G. Montemurro (1993), Modèle cinématique de la zone Subandine du coude de Santa Cruz (entre $16^{\circ} \mathrm{S}$ et $19^{\circ} \mathrm{S}$, Bolivie) déduit de la construction de cartes equilibrées, C. R. Acad. Sci., Ser. II, 317, 1477-1483.

Baby, P., P. Rochat, G. Mascle, and G. Herail (1997), Neogene shortening contribution to crustal thickening in the back arc of the central Andes, Geology, 25, 883-886, doi:10.1130/0091-7613(1997) 025<0883:NSCTCT $>2.3$.CO; 2

Barke, R., S. Lamb, and C. MacNiocaill (2007), Late Cenozoic bending of the Bolivian Andes: New paleomagnetic and kinematic constraints, J. Geophys Res., 112, B01101, doi:10.1029/2006JB004372.
Barnes, J. B., T. A. Ehlers, N. McQuarrie, P. B. O'Sullivan, and J. D. Pelletierd (2006), Eocene to Recent variations in erosion across the central Andean fold-thrust belt, northern Bolivia: Implications for plateau evolution, Earth Planet. Sci. Lett., 248, 103-118, doi:10.1016/j.eps1.2006.05.018.

Barnes, J. B., T. A. Ehlers, N. McQuarrie, P. B. O’Sullivan, and S. Tawackoli (2008), Thermochronometer record of central Andean Plateau growth, Bolivia $\left(19.5^{\circ} \mathrm{S}\right)$, Tectonics, 27, TC3003, doi:10.1029/ 2007TC002174.

Beck, M. E. (1998), On the mechanism of crustal block rotations in the central Andes, Tectonophysics, 299 , 75-92, doi:10.1016/S0040-1951(98)00199-1.

Beck, M. E. (2004), The central Andean rotation pattern: Another look, Geophys. J. Int., 157, $1348-$ 1358, doi:10.1111/j.1365-246X.2004.02266.x.

Beck, S. L., G. Zandt, S. C. Myers, T. C. Wallace, P. G. Silver, and L. Drake (1996), Crustal-thickness variations in the central Andes, Geology, 24, 407410, doi:10.1130/0091-7613(1996)024<0407: CTVITC $>2.3 . \mathrm{CO} ; 2$.

Bourgeois, O., P. R. Cobbold, D. Rouby, J.-C. Thomas, and V. Shein (1997), Least squares restoration of Tertiary thrust sheets in map view, Tadjik depression, central Asia, J. Geophys. Res., 102, 27,55327,573, doi:10.1029/97JB02477. 
Carlier, G., J. P. Lorand, J. P. Liegeois, M. Fornari, P. Soler, V. Carlotto, and J. Cardenas (2005), Potassic-ultrapotassic mafic rocks delineate two lithospheric mantle blocks beneath the southern Peruvian Altiplano, Geology, 33, 601-604, doi:10.1130/G21643.1.

Carlotto, V. (1998), Evolution andine et raccourcissement au niveau de Cusco $\left(13^{\circ}-16^{\circ} \mathrm{S}\right.$, Pérou) Ph.D. thesis, Univ. de Grenoble, Grenoble, France.

Charrier, R., O. Baeza, S. Elgueta, J. J. Flynn, P. Gans, S. M. Kay, A. R. Wyss, and E. Zurita (2002), Evidence for Cenozoic extensional basin development and tectonic inversion south of the flat-slab seg-

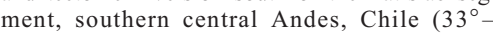
$36^{\circ}$ S.L.), J. South Am. Earth Sci., 15, 117-139, doi:10.1016/S0895-9811(02)00009-3.

Coutand, I., P. Roperch, A. Chauvin, P. R. Cobbold, and P. Gautier (1999), Vertical axis rotations across the Puna plateau (northwestern Argentina) from paleomagnetic analysis of Cretaceous and Cenozoic rocks, J. Geophys. Res., 104, 22,96522,984, doi:10.1029/1999JB900148

Coutand, I., P. Gautier, P. R. Cobbold, M. de Urreiztieta, A. Chauvin, D. Gapais, E. A. Rossello, and O. LopezGammundi (2001), Style and history of Andean deformation, Puna plateau, northwestern Argentina, Tectonics, 20, 210-234, doi:10.1029/ 2000TC900031.

de Urreiztieta, M., D. Gapais, C. Le Corre, P. R. Cobbold, and E. A. Rossello (1996), Cenozoic dextral transpression and basin development at the southern edge of the Puna plateau, northwestern Argentina, Tectonophysics, 254, 17-39, doi:10.1016/00401951(95)00071-2.

Ege, H., E. R. Sobel, E. Scheuber, and V. Jacobshagen (2007), Exhumation history of the southern Altiplano plateau (southern Bolivia) constrained by apatite fission track thermochronology, Tectonics, 26, TC1004, doi:10.1029/2005TC001869.

Ehlers, T., and C. J. Poulsen (2007), A slow and steady growth of the Andean plateau?, Eos Trans. $A G U$, 88(52), Fall Meet. Suppl., Abstract T11G-05.

Elger, K., O. Oncken, and J. Glodny (2005), Plateaustyle accumulation of deformation: Southern Altiplano, Tectonics, 24, TC4020, doi:10.1029 2004TC001675.

Funning, G. J., R. M. D. Barke, S. H. Lamb, E. Minaya, B. Parsons, and T. J. Wright (2005), The 1998 Aiquile, Bolivia earthquake: A seismically active fault revealed with InSAR, Earth Planet. Sci. Lett., 232, 39-49, doi:10.1016/j.eps1.2005.01.013.

Garzione, C. N., P. Molnar, J. C. Libarkin, and B. MacFadden (2006), Rapid late Miocene rise of the Bolivian Altiplano: Evidence for removal of mantle lithosphere, Earth Planet. Sci. Lett., 241, 543-556, doi:10.1016/j.eps1.2005.11.026.

Gil Rodriguez, W., P. Baby, and J. F. Ballard (2001), Structure et contrôle paléogéographique de la zone subandine péruvienne, C. R. Acad. Sci., Ser. II, 333, $741-748$.

Gillis, R. J., B. Horton, and M. Grove (2006), Thermochronology, geochronology, and upper crusta structure of the Cordillera Real: Implications for Cenozoic exhumation of the central Andean plateau, Tectonics, 25, TC6007, doi:10.1029 2005 TC001887.

González, G., G. Dunai, D. Carrizo, and R. Allmendinger (2006), Young displacements on the Atacama Fault System, northern Chile from field observations and cosmogenic ${ }^{21} \mathrm{Ne}$ concentrations, Tectonics, 25, TC3006, doi:10.1029/ 2005 TC001846.

Gregory-Wodzicki, K. M. (2000), Relationships between leaf morphology and climate, Bolivia: Implications for estimating paleoclimate from fossil floras, Paleobiology, 26(4), 668-688, doi:10.1666/00948373(2000)026<0668:RBLMAC $>2.0$. CO 2 .

Hermoza, W., S. Brusset, P. Baby, W. Gil, M. Roddaz, N. Guerrero, and R. Bolaños (2005), The Huallaga foreland basin evolution: Thrust propagation in a deltaic environment, northern Peruvian Andes,
J. South Am. Earth Sci., 19, 21-34, doi:10.1016 j.jsames.2004.06.005.

Hindle, D., J. Kley, O. Oncken, and S. V. Sobolev (2005), Crustal flux and crustal balance from shortening in the central Andes, Earth Planet. Sci. Lett. 230, 113 -124, doi:10.1016/j.eps1.2004.11.004.

Hoke, L., and S. Lamb (2007), Cenozoic behind-arc volcanism in the Bolivian Andes, South America: Implications for mantle melt generation and lithospheric structure, J. Geol. Soc., 164, 795-814, doi:10.1144/0016-76492006-092.

Hongn, F., C. Del Papa, J. Powell, I. Petrinovic, R. Mon, and V. Veraco (2007), Middle Eocene deformation and sedimentation in the Puna-Eastern Cordillera transition $\left(23^{\circ}-26^{\circ} \mathrm{S}\right)$ : Control by preexisting heterogeneities on the pattern of initial Andean shortening, Geology, 35, 271-274, doi:10.1130/ G23189A.1.

Horton, B. K. (2005), Revised deformation history of the central Andes: Inferences from Cenozoic foredeep and intermontane basins of the Eastern Cordillera, Bolivia, Tectonics, 24, TC3011, doi:10.1029/2003TC001619.

Isacks, B. (1988), Uplift of the central Andean plateau and bending of the Bolivian Orocline, J. Geophys. Res., 93, 3211-3231, doi:10.1029/ JB093iB04p03211.

James, D. E., and S. Sacks (1999), Cenozoic formation of the central Andes: A geophysical perspective, in Geology and Ore Deposits of Central Andes, Spec. Publ., vol. 7, edited by B. J. Skinner, pp. 1-25, Soc. of Econ. Geol., Littleton, Colo.

Jordan, T., W. Burns, R. Veiga, F. Pángaro, P. Copeland, S. Kelley, and C. Mpodozis (2001), Extension and basin formation in the southern Andes caused by increased convergence rate: A mid-Cenozoic trigger for the Andes, Tectonics, 20, 308-324.

Kendrick, E., B. A. Brooks, M. Bevis, R. Smalley, E. Lauria, M. Araujo, and H. Parra (2006), Active orogeny of the south-central Andes studied with GPS geodesy, Asoc. Geol. Argent. Rev., 61, 555566.

Khazaradze, G., and J. Klotz (2003), Short- and longterm effects of GPS measured crustal deformation rates along the south central Andes, J. Geophys. Res., 108(B6), 2289, doi:10.1029/2002JB001879.

Kley, J. (1999), Geologic and geometric constraints on a kinematic model of the Bolivian Orocline, $J$. South Am. Earth Sci., 12, 221-235, doi:10.1016/ S0895-9811(99)00015-2.

Kley, J., and C. R. Monaldi (1998), Tectonic shortening and crustal thickness in the central Andes: How good is the correlation?, Geology, 26, 723-726, doi:10.1130/0091-7613(1998)026<0723:TSACTI $>$ 2.3.CO;2.

Kley, J., C. R. Monaldi, E. Rossello, and H. Ege (2005), The Eastern Cordillera of the central Andes: Inherited mechanical weakness as a first-order control on the Cenozoic orogeny, paper presented at 6th International Symposium on Andean Geodynamics, Inst de Rech. Pour le Dev., Barcelona, Spain.

Lamb, S. (2000), Active deformation in the Bolivian Andes, South America, J. Geophys. Res., 105, 25,627-25,653, doi:10.1029/2000JB900187.

Lamb, S., and L. Hoke (1997), Origin of the high plateau in the central Andes, Bolivia, South America, Tectonics, 16, 623-649.

Lamb, S., L. Hoke, L. Kennan, and J. Dewey (1997), Cenozoic evolution of the central Andes in Bolivia and northern Chile, Geol. Soc. Spec. Publ., 121, 237-264, doi:10.1144/GSL.SP.1997.121.01.10.

Maksaev, V., and M. Zentilli (1999), Fission track thermochronology of the Domeyko Cordillera, northern Chile; implications for Andean tectonics and porphyry copper metallogenesis, Explor. Min. Geol., 8, 65-89.

Mamani, M., A. Tassara, and G. Wörner (2008), Composition and structural control of crustal domains in the central Andes, Geochem. Geophys. Geosyst., 9, Q03006, doi:10.1029/2007GC001925.

McQuarrie, N. (2002a), Initial plate geometry, shortening variations and evolution of the Bolivian Oro- cline, Geology, 30, 867-870, doi:10.1130/00917613(2002)030<0867:IPGSVA $>2.0$. CO; 2 .

McQuarrie, N. (2002b), The kinematic history of the central Andean fold-thrust belt, Bolivia: Implications for building a high plateau, Geol. Soc. Am Bull., 114, 950-963, doi:10.1130/0016 7606(2002)114<0950:TKHOTC $>2.0$. CO;2.

McQuarrie, N., and P. DeCelles (2001), Geometry and structural evolution of the central Andean backthrust belt, Bolivia, Tectonics, 20, 669-692, doi:10.1029/2000TC001232.

McQuarrie, N., B. K. Horton, G. Zandt, S. Beck, and P. G. DeCelles (2005), Lithospheric evolution of the Andean fold-thrust belt, Bolivia, and the origin of the central Andean plateau, Tectonophysics, 399, 15-37, doi:10.1016/j.tecto.2004.12.013.

McQuarrie, N., J. B. Barnes, and T. A. Ehlers (2008), Geometric, kinematic, and erosional history of the central Andean plateau, Bolivia $\left(15-17^{\circ} \mathrm{S}\right)$, Tectonics, 27, TC3007, doi:10.1029/2006TC002054.

Mégard, F. (1984), The Andean orogenic period and its major structures in central and northern Peru, $J$ Geol. Soc. London, 141, $893-900$, doi:10.1144/ gsjgs.141.5.0893.

Molnar, P., and C. N. Garzione (2007), Bounds on the viscosity coefficient of continental lithosphere from removal of mantle lithosphere beneath the Altiplano and Eastern Cordillera, Tectonics, 26, TC2013, doi:10.1029/2006TC001964

Mpodozis, C., C. Arriagada, M. Basso, P. Roperch, P. R. Cobbold, and M. Reich (2005), Late Mesozoic to Paleogene stratigraphy of the Salar de Atacama Basin, Antofagasta, northern Chile: Implications for the tectonic evolution of the central Andes, Tectonophysics, 399, 125-154, doi:10.1016/j.tecto.2004.12.019.

Müller, J., J. Kley, and V. Jacobshagen (2002), Structure and Cenozoic kinematics of the Eastern Cordillera, southern Bolivia $\left(21^{\circ} \mathrm{S}\right)$, Tectonics, $21(5)$, 1037, doi:10.1029/2001TC001340.

Oncken, O., D. Hindle, J. Kley, K. Elger, P. Victor, and K. Schemmann (2006), Deformation of the central Andean upper plate system-Facts, fiction, and constraints for plateau models, in The Andes: Active Subduction Orogeny, edited by O. Oncken et al., chap. 1, pp. 3-28, Springer, Berlin.

Ramos, V. A., M. Cegarra, and E. Cristallini (1996), Cenozoic tectonics of the High Andes of westcentral Argentina $\left(30-36^{\circ} \mathrm{S}\right.$ latitude), Tectonophysics, 259, 185-200, doi:10.1016/0040-1951(95) 00064-X

Reutter, K., E. Scheuber, and G. Chong (1996), The Precordilleran fault system of Chuquicamata, northen Chile: Evidence for reversals along arcparallel strike-slip fault, Tectonophysics, 259 , 213-228, doi:10.1016/0040-1951(95)00109-3.

Richards, J., and M. Villeneuve (2002), Characteristics of late Cenozoic volcanism along the Archibarca lineament from Cerro Llullaillaco to Corrida de Cori, northwest Argentina, J. Volcanol. Geotherm. Res., 116, 161-200, doi:10.1016/S0377. 0273(01)00329-8.

Riller, U., and O. Oncken (2003), Growth of the central Andean plateau by tectonic segmentation is controlled by the gradient in crustal shortening, $J$. Geol., 111, 367-384, doi:10.1086/373974.

Riller, U., I. Petrinovic, J. Ramelow, M. Strecker, and O. Oncken (2001), Late Cenozoic tectonism, collapse caldera, and plateau formation in the central Andes, Earth Planet. Sci. Lett., 188, 299-311, doi:10.1016/S0012-821X(01)00333-8

Roeder, D. (1988), Andean-age structure of Eastern Cordillera (Province of La Paz, Bolivia), Tectonics, 7, 23-39, doi:10.1029/TC007i001p00023.

Roperch, P., G. Herail, and M. Fornari (1999), Magnetostratigraphy of the Miocene Corque basin, Bolivia: Implications for the geodynamic evolution of the Altiplano during the late Tertiary, J. Geophys. Res., 104, 20,415-20,429, doi:10.1029/ 1999JB900174.

Roperch, P., T. Sempere, O. Macedo, C. Arriagada, M. Fornari, C. Tapia, M. García, and C. Laj 
(2006), Counterclockwise rotation of late EoceneOligocene fore-arc deposits in southern Peru an its significance for oroclinal bending in the centra Andes, Tectonics, 25, TC3010, doi:10.1029 2005 TC001882.

Rouby, D., P. R. Cobbold, P. Szatmari, D. Demercian, D. Coelho, and J. A. Rici (1993), Least-squares palinspastic restoration of regions of normal faulting-Application to the Campos basin (Brazil), Tectonophysics, 221, 439-452, doi:10.1016/ 0040-1951(93)90172-G.

Rousse, S., S. Gilder, D. Farber, B. McNulty, P. Patriat, V. Torres, and T. Sempere (2003), Paleomagnetic tracking of mountain building in the Peruvian Andes since $10 \mathrm{Ma}$, Tectonics, 22(5), 1048 , doi:10.1029/2003TC001508.

Rousse, S., S. Gilder, M. Fornari, and T. Sempere (2005), Insight into the Neogene tectonic history of the northern Bolivian Orocline from new paleomagnetic and geochronologic data, Tectonics, 24, TC6007, doi:10.1029/2004TC001760.

Sempere, T., G. Herail, J. Oller, and M. G. Bonhomme (1990), Late Oligocene-early Miocene major tectonic crisis and related basins in Bolivia, Geology, 18,946-949, doi:10.1130/0091-7613(1990) 018<0946:LOEMMT>2.3.CO;2.

Sempere, T., G. Carlier, P. Soler, M. Fornari, V. Carlotto, J. Jacay, O. Arispe, D. Neraudeau, and J. Cardenas (2002a), Late Permian-Middle Jurassic lithospheric thinning in Peru and Bolivia, and its bearing on Andean-age tectonics, Tectonophysics, 345, 153-181, doi:10.1016/S0040-1951(01)00211-6.
Sempere, T., et al. (2002b), Lithospheric-scale transcurrent fault systems in Andean southern Peru, paper presented at 5 th International Symposium on Andean Geodynamics, Inst. de Rech. Pour le Dev., Toulouse, France.

Sheffels, B. M. (1990), Lower bound on the amount of crustal shortening in the central Bolivian Andes, Geology, 18, 812-815, doi:10.1130/0091 7613(1990)018<0812:LBOTAO $>2.3$. CO 2

Siame, L. L., O. Bellier, M. Sébrier, and M. Araujo (2005), Deformation partitioning in flat subduction setting: Case of the Andean foreland of western Argentina $\left(28^{\circ} \mathrm{S}-33^{\circ} \mathrm{S}\right)$, Tectonics, 24 , TC5003, doi: $10.1029 / 2005$ TC001787.

Somoza, R., S. Singer, and A. Tomlinson (1999), Paleomagnetic study of upper Miocene rocks from northern Chile: Implications for the origin of late Miocene-Recent tectonic rotations in the southern central Andes, J. Geophys. Res., 104, 22,92322,936, doi:10.1029/1999JB900215.

Steinmann, G. (1929), Geologie von Peru, 448 pp. Karl Winter, Heidelberg, Germany.

Tassara, A. (2005), Interaction between the Nazca and South American plates and formation of the Altiplano-Puna Plateau: Review of a flexural analysis along the Andean margin $\left(15^{\circ}-34^{\circ} \mathrm{S}\right)$, Tectonophy sics, 399, 39-57, doi:10.1016/j.tecto.2004.12.014

Taylor, G. K., B. Dashwood, and J. Grocott (2005), Central Andean rotation pattern: Evidence from paleomagnetic rotations of an anomalous domain in the fore-arc of northern Chile, Geology, 33, 777-780, doi:10.1130/G21876.1.
Taylor, G. K., J. Grocott, B. Daswood, M. Gipson, and C. Arévalo (2007), Implications for crustal rotation and tectonic evolution in the central Andes fore arc: New paleomagnetic results from the Copiapó region of northern Chile, $26^{\circ}-28^{\circ} \mathrm{S}, J$. Geophys. Res., 112, B01102, doi:10.1029/2005JB003950.

Tomlinson, A., and N. Blanco (1997), Structural evolution and displacement history of the West Fault System, Precordillera, Chile, Part 1, Synmineral history, paper presented at 8th Congreso Geológico Chileno, Antofagasta, Antofagasta, Chile.

Tomlinson, A., C. Mpodozis, P. Cornejo, and C. F. Ramírez (1993), Structural geology of the Sierra Castillo-Agua Amarga fault system, Precordillera of Chile, El Salvador-Potrerillos, paper presented at 2nd International Symposium on Andean Geodynamics, Inst. de Rech. Pour le Dev., Oxford, U. K.

C. Arriagada, Departamento de Geología, Universidad de Chile, Casilla 13518, Correo 21, Santiago, Chile.

P. R. Cobbold and P. Roperch, Géosciences Rennes, UMR6118, Université de Rennes, Campus de Beaulieu, CNRS, Rennes F-35042, France. (pierrick. roperch@ird.fr)

C. Mpodozis, Antofagasta Minerals, Ahumada 11, Oficina 602, Santiago, Chile. 